\title{
Playing Poker with the Rule of Law: The United Nations and International Peacebuilding Strategies during the Eritrean-Ethiopian War
}

\author{
Scott Nicholas Romaniuk \\ Department of Politics and International Relations, University of Aberdeen \\ Aberdeen, AB24 3QY United Kingdom \\ Tel: 44-122-427-2726Ｅ-mail: Scott.N.Romaniuk@gmail.com \\ Christopher Douglas Mott \\ School of International Relations, University of St. Andrews \\ College Gate, North Street, St. Andrews, Fife KY16 9AJ, United Kingdom \\ E-mail: Tarkhan.Mott@gmail.com
}

\begin{abstract}
While the abrupt dissolution of the Soviet Union into its component republics was seen by many as an era de novo, and the essential ingredient for outlawing warfare and widespread conflict, others within the analytic community regarded this turning-point as both an 'end' and a 'beginning'. Though the world had seemingly moved beyond bipolarity, events in many global corridors served as sharp demystification of cataclysmic expectations and suppositions of a new age of international peace and stability. The Cold War was, however, a development of enormity that was congruous with renewed conflict and confrontation, yet it enabled the United Nations (UN) to assume a greater role within the orbit of international affairs, including peace operations and mediation. In spite of its new reach and functions, the UN's early experience in peace-building as well as security and stabilization operations proved wholly insufficient for resolving conventional conflict between precarious nation-states. It some cases, the role assumed by the UN and its subsidiaries proved injurious to regional peace and security. Through an examination of the Eritrean-Ethiopian War, this article exemplifies the UN's deficiency in international mediation and that manifestations of nation-building detracted from its responsive capacity to external communication intended to induce a speedy and solid peace-agreement. Ergo, while the UN was not prepared to handle a situation with large set-piece battles involving conventional armed forces, the conduct of the international organization precipitated a war that has lasted well beyond its own natural expiration, and once again proving the unsuitability of the UN to manage international peace-building operations amid such circumstance.
\end{abstract}

Keywords: Civil war, Borders, International law, mediation, nation-states, Organization of African Unity (OAU), Peace-building, Resolution, Total war

\section{Introduction}

It may be a war no one wants, over land rich in dust, between people who until recently regarded each other brothers and sisters in arms.

\section{-The Washington Post, 1998}

Conflict between nations will continue to arise. The real issue is whether they are to be resolved by force, or by resorting to peaceful methods and procedures, administered by impartial institutions. This very Organization itself is the greatest such institution, and it is in a more powerful United Nations that we seek, and it is here that we shall find, the assurance of a peaceful future.

\section{-Haile Selassie I of Ethiopia}

With the end of the Cold War, many quarters of the international political scene were dominated by the illusory myth that the age of large-scale warfare and conventional confrontation was over. The United Nations (UN), along with various regional groups and social organizations began to assume a much heightened role within the international system based upon the premise of gesta non verba. There being no longer any nuclear brinksmanship over strategic spheres of influence, hope blossomed that international mediation between nation-states would enjoy levels of success hitherto unimaginable.

While the UN was acquiring considerable levels of experience within the fields of peace-building and police-operations in Bosnia, most of the conflict-prone corridors of the world were regarded as merely low-level or 
unconventional wars wherein one or more parties were not recognized as sovereign state entities. This experience led the UN to undertake international mediation methods and employ subsequent strategies for the proliferation of peace in manners that proved to be heavily insufficient for resolving major conventional conflict between two recognized states engaged in conventional warfare. The conflict that would highlight this deficiency would be the outbreak of a border conflict between the two countries of Eritrea and Ethiopia (Jacquin-Berdal and Martin Plaut, 2005).

Through a multifactorial analysis that identifies the intracacies of war and nation-building, this article presents an incisive examination of the Ethiopian-Eritrean border conflict and the role of the United Nations and various politcal agents, as well as economic development, currencies, an Ethiopia's geographical locale. By exploring the rupture's many constituents, including what interventionist actions were implemented, and what prospects for peace-building existed, it is demonstrated that the UN's efforts to mediate and meliorate the dispute were ultimately enervated through a lack of dynamism and by agents acting mala fide, rendering efforts to solve the conflict as conditioned by circumstances and external conventions.

\section{Meddlers or Mediators?}

\subsection{International Engagement}

Conflict in the Horn of Africa has been the attention of human rights activists, political advocates, conflict analysts, and peace practitioners from around the world. The rise in attention has been fuelled by an increase in support by international mediation actors as well. Since mediation mechanisms represented a central component of the attempt to diffuse the conflict in this region of Africa, the need to probe underlying concepts of mediation and mediation practices is here necessary. According to Honeyman and Yawanarajah, mediation is the process whereby:

[...] a third-party neutral assists in resolving a dispute between two or more other parties. It is a non-adversarial approach to conflict resolution. The role of the mediator is to facilitate communication between the parties, assist them in focusing on the real issue of the dispute, and generate options that meet the interests or needs of all relevant parties in an effort to resolve the conflict (Honeyman and Yawanarajah, 2003).

This form of intermediary engagement differs from arbitration - a form of alternative dispute resolution (ADR) - in which a decision reached is subsequently agreed upon by the various parties involved in the process. Since the role of the mediator is to (a) assist in and maintain the channels of communication between the disputing parties; (b) facilitate the scope of concentration; (c) focus on specific issues that represent the crux of the conflict; (d) generate options and pathways to peace, the mediator represents a non-adversarial and impartial agent. The formulation of understanding and strategies that may lead to an established peace between the parties should ultimately meet the needs of all relevant parties.

By following pari passu the primary objectives established as part of the mediation strategy, the mediator strives to resolve the conflict, and not to merely mask the issue or to placate conflicting parties by way of superficial means. This in mind, thus calls into question the conduct and role of both the efficacy of the African Union (AU) and the objectivity on the part of the UN during the peace-building processes of the Eritrean-Ethiopian conflict. However, even with the inherent obstacles that surface during mediation processes of conflict scenarios, negotiation is a vital tool in the emergence of peaceful outcomes:

Even when conflicts are seemingly intractable, they sometimes yield to mediation. Mediation is of particular importance in long-running, deep-rooted conflict, as this type of conflict is rarely resolved without such outside assistance. Even if the full-range of grievances cannot be resolved, mediation is often useful for dealing with particular limited aspects of the wider conflict (Honeyman and Yawanarajah, 2003).

The UN utilizes political skills without the application of military force, and in accordance with the UN Charter, in an effort to act as a third party in conflict situations. As demonstrated in the lead-up to and during the conflict, mediation skills may be offered in the following forms:

(a) Prior to conflict through preventive diplomacy;

(b) During a conflict through peacemaking activities;

(c) After a conflict to promote implementation modalities and agreements;

(d) During peacemaking efforts to consolidate peace and lay the foundation for sustainable development ( Honeyman and Yawanarajah, 2003).

\subsection{Pinpointing UN Mediation Laxity}

Although a variety of mediation skills may be employed by the UN, the mandate followed by the Organization holds a sharper focus in such instances. When the UN engages conflicting parties, those parties enter into an agreement 
whereupon a mediation mandate is implemented. In essence, said parties formally accept the fact that the UN is acting as mediator serving in the best interests of those parties. An acute problem associated with this relationship rests within the capacity of the mediator in question, in this case the UN, to act in the best interests of both parties when ultimately those very interests are sought by more than a single party involved in the conflict. The UN, however, may also employ external advisers in an effort to construct a workable plan for peace.

Given the circumstantial potential for creating obstacles as that mentioned above, a major conflictual reality is here revealed. An organization that is expected to demonstrate its capacity to act in the best interest(s) of both disputants may favour one over the other, and may even act in accordance with serving the long-term strategic interest(s) of the mediator - in this case the African Union. In short, it is simply impossible for any human being or organization to be truly neutral, even though mediators believe strongly in and pride themselves on their objectivity and neutrality. However, it may be said that the utilization of biased mediators can be even more effective than mediators that claim neutrality. This is so given that the concept of raw neutrality is purely unattainable; therefore, making public the mediation-bias represents a step towards insulating the mediator from accusations of misconduct.

The UN mediation mandate offered both Eritrea and Ethiopia a distinct opportunity to "[...] avail themselves of the experience and best practices that the United Nations, as an organization, has gained in the field of conflict resolution" (Stanley and Holiday, 1997:28). In nearly every case, however, the mediator cannot enforce an outcome. The chief concern of the mediator is to generate a constructive and beneficial dialogue between all disputants, and to a standard much higher than could have been achieved without mediation. In one sense, is may be safely argued that the UN stumbled over Eritrea and Ethiopia in much the same way that it stumbled over its own clumsy impartiality principles during the mediation, verification and institution-building in El Salvador during the early 1990s, whereby the "[...] verification dilemma was compounded by tensions between the UN's duty to verify stringently and its need to maintain an image of impartiality" (Stanley and Holiday, 1997:28).

A second major enigmatic obstacle to the establishment of a recognized and respected peace-building arrangement can be seen in the area of ensuring observance of or obedience for the decisions that are reached by the mediating agents. Multilateral aid, for example, should be conditional on the Ethiopian and Eritrean governments ending their disputes, since conflict resolution is in the best interest of both nation-states, employing a measure of economic and financial incentive or monetary carrot and stick policy is one such method through with the observance of mediator's decisions might well be ensured. This can be particularly useful in the case of developing countries that are heavily dependent on the flow of foreign-aid in order to sustain political and economic lifelines of the country and those living within its borders. In essence, there must be a consequence to any nation's refusal to comply with the instructions as established by mediating bodies.

A third major impasse to the establishment of a workable peace-building configuration may be found among the mechanisms that drive the mediation process on an organic level. As the Boundary Commission comprised legal representation, name lawyers, it may be safely argued that the peace-building architecture that centred on Badme was flawed from the beginning. Lawyers typically approach mediation from a problem-solving point of departure - that is, mediation that focuses inherently on settlement. This is precisely what had taken place during the design and implementation of the Badme peace-settlement. Unfortunately, many within the legal community are often misguided by the belief that mediation is more than a normative force through which a speedy and efficient settlement is almost always easily achieved. Such a short-sighted approach typically leads to the resurrection of conflict scenarios, often with much larger and more violent consequences that were realized previously. A more intelligible approach is represented by those within the analytic community who understand that disputants will almost always have to deal with each other again in the future. Thus, a settlement designed to impose, rather that guide or instruct disputing parties is bound to deliver less than favourable outcomes in the end.

\section{Power and War in the Horn of Africa}

Though the current nexus of the Eritrean-Ethiopian rivalry lies within a disputed border, the conflict has many facets. This border rivalry is the flashpoint of recent relations between the two countries; like many international disputes of the present period, the contested border is rooted within its own colonial narrative. Though Ethiopia, with the exception of a brief Italian occupation in the 1930s until the outbreak of hostilities within Europe in 1939, always remained independent and succeeded in defeating an Italian invasion in the late nineteenth century, Eritrea was very much a colony of Italy. Italy and Ethiopia therefore brought their difference to the table at the turn of the twentieth century to discuss the official border of their respective states and to draw a map to settle their differences. This map, completed in 1907 (Henze, 2001), was intentionally vague on the part of Italian cartographers to give the colonial authorities of Eritrea room to make additional territorial claims in the future. 
When the Italians invaded Ethiopia again - and this time with much more success - in 1936 these ambiguously demarcated borderlands were given to the colony of Eritrea. Ethiopia was mostly subjugated with the Emperor Haile Sellassie fleeing the country still appealing for help from the international community. In 1941 British troops ejected the Italians from Eritrea and administered it as an occupied enemy province. The United States (US), however, reached an agreement with Ethiopia that Eritrea would be turned-over to Ethiopia as a protectorate with domestic autonomy within a Federation system. This transfer of power occurred on 15 September 1952 ( Henze, 2001).

Emperor Haile Sellaisse was a thoroughly absolute monarch, and so he began almost immediately to undermine the domestic autonomy given to Eritrea by the Federation treaty. This sparked uprisings and guerrilla movements which, in conjunction with a devastating famine, toppled the traditional monarchy of Ethiopia and led to its replacement by Mengistu Haile Miriam's Communist Derg (also "Dergue") government (Kumar, 1998). The Derg continued the centralization and collectivization processes which in turn exacerbated the civil war and the food crisis. It was at this juncture that two allied, and yet also rival, Marxist groups began to form in opposition, the Eritrean People's Liberation Front (EPLF) and the Tigrayan Peoples Liberation Front (TPLF) both fought the Derg from bases in Eritrea and Ethiopia, respectively. Both of these groups worked closely together to eventually overthrow the Derg, and when victory was achieved the TPLF, now in charge of Ethiopia, recognized the independence of Eritrea under the EPLF and the two countries peacefully separated (Negash and Tronvoll, 2000). It seemed that the saga of strife between the two neighbours was at an end.

Such a lull in the fractious relationship was not to last. It became increasingly apparent that Eritrea wished to more fully divest itself from a past that could be perceived as tied to Ethiopia. The first step was to aggressively assert Eritrea's interests against its neighbours. Sudan was publicly accused of attempting to undermine Eritrean sovereignty in 1994 and a border dispute with Yemen over the legal status of the Hanish Islands in the Red Sea led to a rise of tensions throughout the region. President Isias Afwerki of Eritrea certainly had to contend with the dangers of guiding a newly established state through the minefield of neighbourly relations and schemes, but this overly assertive attitude, backed up by a history of Eritrean military success and mass mobilization - including the female population - was proving domestically popular (Henze, 2001).

That was not the only item of contention that drove the two countries apart. Since independence, the Eritrean economy was tied to the Ethiopian Birr currency. Since trade with Ethiopia amounted the majority of international trade for Eritrea and that the Birr was a strong and stable currency - by regional standards at least - this was a logical decision. By 1997 however, Eritrea decided it was time to introduce their own currency, the Nakfa. The Nakfa had no backing and greatly damaged Eritrean trade relations as many governments would not take what they saw as worthless currency, Ethiopia especially (Jacquin-Berdal and Plaut, 2005).

With a potential economic downturn and the possibility of subsequent domestic unrest, both countries turned to their border disputes. These issues had been relegated to the back-burner for some time but as relations continued to deteriorate their pre-eminence in the inter-state relations of the two countries began to augment. Many regions along the border were nebulous and any number of them could have become a flashpoint, but the largest region that fell into dispute was Badme. Ethiopia began sending police and militia into the region to exert its hold on the area and within a few weeks Eritrea responded by launching its army across the border and driving these scant forces out on 8 May 1998 (UN Security Council; UN, 2001).

The quick campaign was then extended to other disputed regions and once seized; the territories were fortified with extensive trenches and fire bases. Eritrea knew that Ethiopia had a much larger base of manpower and military, and hoped that by holding-out and inflicting massive casualties on the Ethiopian army, as it tried to dislodge them, it could both make the larger power look like an aggressor and wear-down Ethiopia's internal cohesion through the long battle of attrition that would occur. Eritrea also hoped a victory on the international stage would help procure a greater degree of recognition, especially with respect to their currency. This was a two-pronged strategy involving funding for the Oromo separatist groups (Mockler, 2002) in eastern Ethiopia as well as establishing ties with Somali warlords who had anti-Ethiopian agendas (Negash and Tronvoll, 2000).

Although Ethiopia was also building-up its forces, it was completely taken aback by the speed and sudden nature of the assault. Amid a backdrop of open conflict, President Meles Zenawi stated that, "Ethiopia demands the Eritrean government's unconditionally and immediately withdrawal from Ethiopian territory and cease its provocative and belligerent activity" (Negash and Tronvoll, 2000:75). In response, the Eritrean government released its own statement averring that an Eritrean military force had been fired upon when approaching the Ethiopian garrison for dialogue, and had responded accordingly, which led to a subsequent cycle of clashes that precipitated the seizure of what they referred to as "Southern Eritrea" (Negash and Tronvoll, 2000). 
Immediate attempts to retake the area produced large Ethiopian casualties with no progress at dislodging the fortified Eritrean positions. In a grim spectacle familiar to Western Europe, the Ethiopian army marched against trenches protected by barbed wire and fixed machine gun nests. Ethiopia suffered enormous casualties as a result of this archaic style of warfare. A full-scale war had now broken out, and the combined forces of the US, Rwanda, the Organization of African Unity (OAU) and the UN had failed remarkably to stop the bloodshed.

\section{False Optimism: Peace through War?}

Attempts at resolving the conflict had broken-down for the immediate participants in the struggle, but elements of the international community almost immediately began to step-up with proposals and offers of mediation. The US, which in the Cold War had all but abandoned the Horn of Africa to alternating cycles of Chinese and Soviet influence, decided at that point that it was in its interest to solve the crisis by drawing the war to conclusion as soon as possible. There were several reasons for the US' involvement, which mostly stemmed from the feared levels of regional instability that would occur in light of such a large war taking place between two impoverished countries. However, the most pressing of these concerns was the belief that this full-scale conflict between a majority Christian state and a majority Muslim state - though each had significant members of many religions within their own borders - would lead to a rise in influence of radical Islamic factions based in Somalia and Sudan, causing them to extend their influence into Eritrea and the rebellious Ethiopian province of Oromo (Foreign Policy in Focus, 2000).

A secondary objective in bringing the war to a swift end was to prevent the isolated nation of Sudan from re-establishing normative relations with both Eritrea and Ethiopia, as Sudan and the US were at odds on several issues at this juncture. In order to gain leverage on this matter the US decided to work with its local ally Rwanda, which owing to its recent experiences in violent conflict scenarios, felt that it could lend a hand in negotiations, and of course increase its local prestige at the same time (Jacquin-Berdal and Plaut, 2005). The US-Rwanda peace plan was designed with a few key principles in mind, which can be summarized from the US press statement accordingly:

(a) Both parties should commit themselves to the following principles: resolving this or any other dispute between them by peaceful means and renouncing force as a means of imposing solutions;

(b) To reduce current tensions by removing armed forces from the border and allowing a UN be deployed between the two armies;

(c) To create a lasting resolution by having both parties adopt a permanent and binding compromise peace;

(d) And to demilitarize the entire common border as soon as possible (Negash and Tronvoll, 2000).

Both nations in the dispute reasoned that sending relatively inexperienced and - in the view of Eritrea and Ethiopia lower ranking representative of the State Department, Assistant Secretary of State Ms. Susan Rice as a sign that the US places scant priority in solving the conflict. As a result, they were of the belief that any involvement by the American officials at this point in the conflagration would be considered half-hearted at best (Jacquin-Berdal and Plaut, 2005). The OAU soon met and decided to back the plan, presenting it to the leaders of both antagonists. This plan was quickly criticized by both sides of the conflict for various reasons. On one hand, Eritrea thought that the OAU, having its base in Addis Ababa, was a biased source stacked with member-states hostile to Eritrea's interest - Djibouti, which now served as Ethiopia's primary source of seaborne trade, including weapons, was singled out - and that Ethiopia's increasing rates of mobilization showed that they were consumed with the idea of waging total war.

On the other hand, Ethiopia criticized this peace plan as rewarding aggression by showing the parties in an equal light when Eritrea had clearly initiated hostilities. Despite such overarching reservations, Ethiopia was caught off guard by the sudden assault and was desperately trying to hold the line, so the Ethiopian government accepted the plan. In an unfortunate state of affairs, Eritrea did not represent itself as so willing to accept the plan. As a result, the war continued (Negash and Tronvoll, 2000). Eritrea, in fact, so offended Djbouti with the accusations of bias that Djibouti cut of diplomatic relations with Eritrea - Eritrea as well, severed its ties - and began to overlook the arms embargo ostensibly placed on the area by allowing even more arms to be shipped to Ethiopia. This action can be explained by previous border disputes Djibouti had with Eritrea and thus, in all likelihood, it really was a biased player in the negotiations (Jacquin-Berdal and Plaut, 2005).

Negotiations, like the early Ethiopian offensives, stalled, but in the meantime Ethiopia was marshalling its superior reserves of population and military resources for the counter-attack. The policy of attrition and occupation in conjunction with undermining the internal cohesion of the Ethiopian state was not working. In fact, aside from the usual flaring-up of rebellion in the Oromo territory, it seemed that Ethiopia was if anything more united by the war than it had been before (Henze, 2001). Indeed, soon Eritrea would deeply regret its decision to bring about a major war. The escalation had already brought about aerial bombardment of cities on towns in both countries, including an air raid on the Eritrean capitol, Asmara. Then, over the course of February, 1999, the war reached a decisive climax. 
The newly marshalled legions of Ethiopia, coordinating tanks, air support, artillery, and massive infantry attacks, attacked the main strongholds of the Eritrean army. The tanks broke through far away from the front and turned to surround the Eritreans while the infantry attacked from the front. The result was almost total annihilation of the Eritrean army on that front. 'Operation Sunset' - so named because Eritrean president Afwerki claimed that Eritrean troops would hold the positions as long as the sun continued to rise - completely reversed the fortunes of the war (Negash and Tronvoll, 2000).

It was at this juncture that the diplomatic norms of Eritrea rejecting peace mediation and Ethiopia pushing for it began to reverse themselves. Eritrea, now knowing that the war was lost, immediately stated its acceptance of the peace as outlined in the OAU's framework. Ethiopia however, now riding a wave of victory with its troops driving deep into Eritrea proper, expressed a newly found reluctance to end a war it viewed as being waged by an aggressor that now had become a costly but indisputable victory for the arms of Ethiopia. The government in Addis Ababa repeated its previously muted criticism of the peace plan on the grounds that it was awarding the party that initiated hostilities by treating the countries as equals when Ethiopia had followed international law and Eritrea had broken it. In Ethiopia's eyes, Eritrea had gone looking for trouble, but when Eritrea got the better end of it, put on a show of victimhood.

As the armies continued to advance, however, it became apparent to Ethiopia that it was increasingly being seen as unreasonable. Hundreds of thousands of refugees had been created by the war and casualties on both sides had been immense. Given that Ethiopia had such a large advantage of power it was being increasingly perceived by the international community as the aggressor nation. These factors finally forced the hand of the Ethiopians, and they too agreed to peace talks (Foreign Policy in Focus, 2005). It is important to note that it was this fear of negative backlash to Ethiopia's image that stopped the war, not any change in the peace proposals by the UN or possibility of action on the part of foreign governments.

\section{The Role of the African Union (AU): Mediator or Matchstick?}

The overall failure of the UN in neutralizing hostilities and military aggression in the Horn of Africa were mirrored spectacularly by the incapacity of the AU to establish peace in the region. Working amid a trend toward greater democracy, freedom, and peace in African nation-states, the AU's failure hinged heavily on its Ethiopian-leanings and disregard for Eritrean rights and security concerns. In this sense, the AU's democratic backslide led to a fundamental flaw in its formal diplomacy, resulting in outright failure in its broad-based peace-recovery operation. Since the AU's strategy was seen as pro-antagonist, little hope presented itself for a rapid and rebound from warring parties, unless external mediation parties could become heavily involved. Unfortunately, we find that the primarily engine for peace was also unable to consider external recommendations and suasion in its comprehensive peace architecture.

It should be here emphasized that Ethiopia's status among other AU member-states as the home-base of the Union drew a wedge between the Union and its ultimate ability to function during the border-dispute. As Zondi and Réjouis argue:

[...] the AU has offered very few fresh initiatives besides the same diplomatic missions as the UN had offered and which Eritrea had rejected at the outset as showing their ( $A U$ and $U N$ ) lack of confidence in international law. Thus, Eritrea has virtually lost faith in the AU as a forum for furthering its strategic regional interest and recalled its ambassador to the $A U$ in November 2003 (Zondi and Réjouis, 2006:77).

Prudential decision-making in terms of mechanisms that are suitable for dealing with conflicts between the parties, a failure to find adequate internal support for facilitating peace-operations, and heavy attempts by the Eritrean government to undermine economic and security bases of Ethiopia represent three realities that augmented the aggressive relations between the two nation-states. These imperatives also greatly inflated the difficulty in fostering peace in the region as the UN demonstrated a major failure by seeking to create something other than a win-win scenario.

Since international peace-building and arbitration is rooted in mediators' abilities to ascertain root-causes of conflict, and isolate factors in an attempt to assuage the fundamental differences that cause the conflict, the UN employed an overly authoritative strategy that sought to dictate terms to both parties as opposed to employing mediation strategies that would grant both parties equal powers. As noted by Zondi and Réjouis, "consequently, arbitration allows the vindication of a winner and the humiliation of a loser" (Zondi and Réjouis, 2006:77).

The main debilitating component of the imposed-peace by the United Nations and that sought by the African Union, was the assumption that both parties would openly accept the recommendations of the UN As the primary mediator tasked with delivering peace to Ethiopia and Eritrea. Instead, the myopic peace that was imposed should in no way be regarded as an "agreement" or "settlement". Rather than seeking to establish and implement a more nuanced, if regrettably complex, pathway to peace, the UN extended the conflict's expiration date through superficial approaches 
and expectations. Eritrea, "already the winner in this case was bound to prolong rather than end the conflict" (Zondi and Réjouis, 2006:77).

\section{No War, No Peace}

\subsection{A Symbol of Failure}

The initial peace deal forced both sides to redeploy in their own borders at a distance of at least 25 kilometres from each other - maximum artillery range - and to agree to halt all air-strikes. A demilitarized zone was established, mostly on the Eritrean side of the border, reflecting the Ethiopian military victory, and UN peacekeepers entered the space with a contingent of cartographers to accurately plot out the border. However, in her letter addressed to the President of the Eritrea-Ethiopian Boundary Commission, President Isaias Afwerki of Eritrea affirmed the unjust nature of the Commission's decision, which was later televised throughout Eritrea in the following terms:

Furthermore, in her letter dated 29 letter, addressed to the President of the Eritrea-Ethiopia Boundary Commission, the Eritrean Legal Advisor to the President acknowledged as 'both final and valid' the demarcation coordinates that the Commission has specified, while stressing that the Eritrea also considered these coordinates 'as binding as other Commission's decisions'. For its part, Ethiopia has maintained its position that demarcation by map coordinates has no legal force or effect. In a letter addressed to President of the Eritrea-Ethiopia Boundary Commission on 27 November 2007, the Minister of Foreign Affairs of Ethiopia stated that the 'demarcation coordinates are invalid because they are not the product of a demarcation process recognized by international law' (UN Secretary-General, 2008).

Eventually the Commission reached the understanding that both sides were claiming too much territory and various regions were assigned to either Eritrea or Ethiopia respectively (Eritrea-Ethiopia Boundary Commission [Referred to hereafter as the "EEBC"], 2002). The root cause and pre-eminent symbol of the border dispute, the town of Badme, was placed within Eritrean jurisdiction. Nonetheless, both countries agreed to the treaty, known as the Algiers Agreement, which was drafted between 2000 and 2002 (EEBC, 2002). However, by 2003 Ethiopia reversed its decision and attempted to have a new Border Commission investigate the placement of the town of Badme (UN, 2003). This proposal was largely ignored. Although seemingly settled, the fate of Badme is still nebulous, with neither state truly exerting authority over the small town. To further complicate matters the town's inhabitants consider themselves Ethiopians, despite lying within the border of Eritrea (Lyons, 2006). Beyond intervention had not taken into account the local circumstances on the ground.

\section{2 'Algiers': Agreement or Entanglement?}

The purpose of the Algiers Agreement can be summarized through the following four points:

(a) Realize a permanent conclusion to the all hostilities while pledging not to resort to threats of the application of military force;

(b) Respect the provisions of the conciliation of the cessation of hostilities signed 18 June 2000;

(c) Implement full efforts for the release and repatriation of all prisoners of war and detainees;

(d) Demonstrate a respect for humanitarian treatments towards each others nations living within the borders of both nation-states.

In essence, the Algiers Agreement has summarily wrestled a swath of autonomy from Ethiopia by supporting Eritrea's bid for its de facto 1993 independence. This forms the core of the Agreement's partisan character. The Agreement, "remains irregular in which Eritrea gets everything it never had and Ethiopia loses everything it did have thus far due to the three outdated and inapplicable colonial treaties of 1900, 1902, and 1908 that the Commission attempts to implement based on its own subjective interpretations of the matter" (Imma, 2007). The Commission's inability to negotiate and manoeuvre the provisions demonstrates a basic shortcoming in its capacity to mediate on a principles-based level. To be sure, the same failures in international mediation and mismanagement of international legal frameworks were repeated on numerous occasions, especially during the terminus demarcations that took place along the border.

The demarcation experiment represents the first major African border-alteration by a third party to this day. Since the Commission of the Algiers Agreement handled Eritrea and Ethiopia's case as a "take it or leave it approach" (Imma, 2007), the mediation-style employed was highly inappropriate and bound to fail at some point in the future. In any event, the one-sided approach undertaken by the Commission failed to represent an attitude that sought an indefinite rapprochement between to warring nation-sates. The failure of the Commission's conduct is further demonstrated when considering the fact that neither Eritrea nor Ethiopia were afforded adequate time in managing the conflict prior 
to intervention by external institutions. Thus, the probability of cooperation between the two states was never appropriately guaged, nor was the potential for alternative solutions tested.

The Commission was established pursuant to the 12 December 2000 Algiers Peace Agreement between Eritrea and Ethiopia. The UN Cartographer is the Secretary to the Commission. The PCA in The Hague serves as the Commission's seat and registry. The Members of the Commission are Sir Elihu Lauterpacht CBE QC (President), Prince Bola Ajibola SAN KBE CFR, Professor Michael Reisman, and Judge Stephen M. Schwebel (Eritrea-Ethiopia Boundary Commission, 2007). While the Boundary Commission represents one neutral entity within the Agreement's framework, the second neutral commission that was created in order to facilitate a peaceful conclusion to the conflict was the Claims Commission, and both were located in the European Union (EU), specifically at The Hague.

The Algiers Agreement failed to consider any viable option that was put forward by the Ethiopian government, prior to the implementation of its own mediation and settlement agenda. Unfortunately, the plan moved by Ethiopia's President held promise, if the $\mathrm{UN}$ and the Commission were willing to consider them as part of the mediation or peace agreement. At the very least, considering the particularities of the Ethiopian points would have presented a rudimentary framework from which to launch a more organic and potentially equitable plan for lasting peace. One of the most astonishing, and perhaps missed-opportunities that were embedded within the proposal by Ethiopia was the suggestion to enter into dialogue between the two African states. The plan represented far more than an empty gesture, while it did present a measure of flexibility, particularly as it pertained to the proposed demarcation line along the states' frontiers.

Even though members of the Eritrean polity refused to consider any parts of the Ethiopian proposal, both Commission and the UN could have swayed Eritreans into considering the terms. By this time, however, it was too late to encourage Eritreans to hold good faith in the Ethiopian proposal since it was delivered after the Commissions' overtures. Thus, another major failure of the Algiers Agreement is here revealed. Had neither Commission acted with such haste in designing and delivering terms to both nation-states, still other avenues and pathways to peace, perhaps long-lasting if not indefinite peace, may have been more readily achievable than previously realized. Eritrean dismissal of Ethiopia's five points should have served as an indication of the deeper animus between these peoples. This sentiment is represented in clear terms, when Imma explains:

[...] if lasting peace is expected to be brokered between the two sisterly nations, lost opportunities and sources of constant tensions must be dismantled and dealt with once and for all. In particular, discontents consistently coming to the fore by concerned Ethiopians must be given priority as their opinions are neither second thought nor interpretations by external agents. These are first hand thoughts with deep sited concerns of one's own nation. In the eyes of the overwhelming majority of Ethiopians, the Meles Zenawi's regime took its own premature, hasty and presumptuous thoughts to the Algiers meeting without much deliberation was done by Ethiopian stakeholders on the deal especially concerning substantial national factors as the ones mentioned herein and thus far. In actual fact, Ethiopia's access to the sea and the fate of the two-million Afar populations should have been exhaustively examined in preparation for likely negotiations during the meetings in Algiers. Consequently Ethiopians remain disappointed with the whole process of the Agreement attempted thus far (Imma, 2007).

After carefully assessing its options, the Commission realized that targeting Ethiopians as measurably more contrite and domicile than their Eritrean counterparts by favouring Eritrea in its settlement was a quick and simple solution. This decision alone lends itself heavily as the cause of ongoing conflict between Eritrea and Ethiopia, without realizing any consequences of its own. Having affiliated itself with no specific nation-state or national polity, the Commission was able to isolate the enmity of the decision and contain it within the tunnel of Eritrean-Ethiopian relations. The distasteful and pitifully-managed settlement has been explained through equally negative repose:

It was actually a mistaken and poorly planned accord that still attempts to keep Ethiopia in a trap without any provision for its legitimate exit to the sea. For this reason, realizing the Algiers Agreement becomes gravely wrong as it fails to address the hitherto mentioned most primary and deep-seated Ethiopian security issues and geopolitical interests; indeed it obstructs to naively keep none-consulted and inconclusive agreements alive (Imma, 2007).

Since fumbling along the economic-political axis of Ethiopia's statehood, the Algiers Accord has failed incredibly in creating a highly volatile national security reality for Ethiopia. One such question that arises, and still requires in-depth focus is this: should Ethiopia's geo-strategic relationship with its UN and AU partners be expected to undergo subsequent deterioration as a result of the debacle that has been recorded in this region of Africa, and international mediation? This possibility weighs-in heavily as both international organizations placed regional security as well as Ethiopians at the bottom of the priority list.

\subsection{No Way Out?}

Though the war over the borders has not flared-up again, the situation remains tense. In 2005 Eritrea demanded the withdrawal of the UN observer force in the demilitarized zone (AllAfrica). This led to another phase of troop 
deployment along the zone by both countries and many feared a new war would break-out. The reason for this was that a follow-up study by the UN Claims Commission determined that Badme should be given back to Ethiopia and that Eritrea was responsible for violating international law by attacking Ethiopia (EEBC, 2002). Tensions cooled however and a kind of status quo in the border regions prevailed. This however did not prevent the two countries' rivalries from cropping-up elsewhere. Both sides began to export their conflict into a proxy war fought through rival Somali warlords (Lyons, 2006).

Eritrea held a solid advantage in this shadowy war by backing the Islamic Courts Union (ICU), which was quickly becoming the dominant faction in the country. This was likely one of the primary reasons that Ethiopia, with US encouragement, invaded Somalia to topple the ICU in the summer of 2008. The war is currently ongoing and both Eritrea and Ethiopia are labouriously invested in this fight. Somalia is not the only new front in the conflicts birthed from the border war. On 24 October 2008, Djibouti announced that Eritrean troops were in violation of the border and threatened that war would be the only remaining option if they were not withdrawn (BBC, 2008). Eritrea's prickly relations with its neighbours is a consistent ripple, if not wave, in overriding attempts by non-state actors at diplomacy in the Horn of Africa.

The Border War of 1998-2000 produced about 100,000 casualties and many more refugees (Negash and Tronvol. 2000), and its end result was the acceptance of the joint US-Rwanda peace plan with OAU support, which was proposed at the very beginning of the conflict (Norwegian Council for Africa [NCA], 2003). The conduct of both parties was largely dictated by the circumstances on the ground, where whichever side that was winning would object to the acceptance of the peace proposal as it would be in the losing countries advantage to do so. This can clearly be seen in the flipped positions of Eritrea at the start of the war, and Ethiopia by the conclusion of the conflict. Ethiopia however had no luck in having the UN assist them so it would be understandable if they had lost faith in the international peace process.

The behaviour of local countries also showed that power politics clearly trumped the goals of international organizations with the OAU-member Djibouti not assuming a neutral stance based on its previous relations with Eritrea. The common thread that ties the corpus of failures on multiple levels together is this: the international community could not deal with a major conventional war taking place between two member states, especially when many nations in the international community had direct strategic interests in the conflict. Both countries being recognized UN-members means that they can divide the international community along lines of alliances, leading of course to power-politics simply being enacted at a higher level.

\section{Conclusion}

Having enjoyed success in dealing with conflicts based around intra-state enmity and political factions, the UN was not prepared to handle a situation with large set-piece battles as conventional armed forces manoeuvred and blasted across trenches and borders. The public opinion of the matter must also be considered. When a country wins a large and indisputable victory against a foe, and takes away little or nothing from said victory, it is likely to be an undermining event in the populace's support for engagement with the international community.

The leadership of Ethiopia has accused the US of "saving" Isias Afwerki from ruin by helping the two parties make a peace deal artificially by way of near-equal terms. President Meles Zenawi of Ethiopia stated it best when he accused Eritrea of "playing poker with the rule of law" (Henze, 2001), which was not punished by any non-state actor. Of course, one could apply the same witty anecdote to his leadership of Ethiopia as well. The war still continues, albeit in Somalia, and one wonders if the bungling attempts by the international community, particularly the UN, to resolve the crisis by not allowing one side to walk away from the table victoriously has extended the shock wave of the war well beyond its natural lifespan.

In spite of a constellation of international attention on the border conflict in addition to the seemingly immeasurable degree of effort on the part of the UN and its ancillary political bodies in compiling an arrangement for peace, the prospect of further conflict, further bloodshed, and further regional instability cannot be gainsaid. The resulting tension, violence, and the region's security inconstancy are direct products of the peace-arrangements that were put in place over recent years. The fact that the UN's most recent attempt has contributed to a surfeit of violence and conflict should not be ignored. Rather, the UN's extended failure now registers as one of the Organization's greatest blunders since the cessation of the old Cold-War order.

\section{References}

British Broadcasting Corporation. (24 October 2008). "Djibouti Says Eritrea Risking War," Available at: $<$ http://news.bbc.co.uk/2/hi/africa/7687503.stm>. 
Eritrea-Ethiopia Boundary Commission (EEBC) Decision Regarding Delimitation of the Border between The State of Eritrea and the Federal Democratic Republic of Ethiopia. (13 April 2002). The Hague, Netherlands. Available at: $<$ www.un.org/NewLinks/eebcarbitration/EEBC-Decision.pdf $>$.

Ethiopia-Eritrea: Stalemate could lead to war, Eritrean government says. $<$ www.allafrica.com/stories/printable/200504050401.html.>.

Foreign Policy in Focus. (August 2000). "The War Between Ethiopia and Eritrea," Vol. 5, No. 25. Available at: $<$ http://www.fpif.org/pdf/vol5/25IFEritEthiop.pdf $>$.

Henze, Paul. (2001). Eritrea's War: Confrontation, International Response, Outcomes, Prospects. Addis Ababa, Ethiopia: Shama Books.

Norwegian Council for Africa. (2 October 2003). "Horn of Africa: Ethiopia, Eritrea Peace Process Plunged into Crisis," Inter Press Service (IPS). Available at: <http://www.afrika.no/Detailed/4106.html >.

Honeyman, Christopher and Nita Yawanarajah. (2003). "Mediation," Beyond Intractability: A Free Knowledge Base on More Constructivist Approaches to Destructive Conflict. Available at: $<\mathrm{http} / / /$ www.beyondintractability.org/essay/mediation/>.

Jacquin-Berdal, Dominique and Martin Plaut., (ed.) (2005). Unfinished Business: Ethiopia and Eritrea at War. Asmara, Eritrea: The Red Sea Press.

Kumar, Krishna (ed.). (1998). Postconflict Elections, Democratization, and International Assistance. Boulder, CO: Lynne Rienner Publishers.

Lyons, Terence. (21 December 2006). The Council on Foreign Relations: "Avoiding Conflict in the Horn of Africa: US Policy Towards Ethiopia and Eritrea," CSR No. 21.

Mockler, Anthony. (2002). Haile Selassie's War. Brooklyn, NY: Olive Branch Press.

Negash, Tekeste and Kjetil Tronvoll. (2000).Brothers at War: Making Sense of the Eritrean-Ethiopian War. Athen, Ohio: Ohio University Press.

Siphamandla Zondi and Emmanuel Réjouis. (2006). "The Ethiopia-Eritrea border conflict and the role of the international community," African Journal on Conflict and Resolution (AJCR), 6(2): 69-83.

Stanley, William and David Holiday. (Summer 1997). "Peace mission strategy and domestic actors: UN mediation, verification, and institution-building in El Salvador," International Peacekeeping, 4(2): 22-49.

United Nations Secretary-General. (2008). "Report of the Secretary-General on Ethiopia and Eritrea." Available at: $<$ http://www.mineaction.org/downloads/1/s200840.doc $>$.

United Nations Security Council, progress reports of the Secretary-General on Ethiopia and Eritrea. $<\mathrm{http}: / /$ www.un.org/Docs/sc/presidency/ps0805.htm>.

United Nations, 'Eritrea-Ethiopian boundary commission', 7 July 2003. s/2003/752. <www.un.org/docs.html>.

United Nations Statements on Eritrea and Ethiopia dispute. <http://un.org/Docs/sc/presidency/ps2506.htm>. 


\begin{tabular}{|c|c|c|c|c|c|}
\hline State & Military Observers & Soldiers & Staff & Total & National Support Elements \\
\hline Algeria & 8 & 0 & 0 & 8 & \\
\hline Austria & 2 & 0 & 0 & 2 & \\
\hline Bangladesh & 8 & 0 & 5 & 13 & \\
\hline Bolivia & 3 & 0 & 0 & 3 & \\
\hline Bosnia and Herzegovina & 5 & 0 & 0 & 5 & \\
\hline Brazil & 7 & 0 & 0 & 7 & \\
\hline Bulgaria & 4 & 0 & 0 & 4 & \\
\hline People's Republic of China & 7 & 0 & 0 & 7 & \\
\hline Croatia & 4 & 0 & 0 & 4 & \\
\hline Czech Republic & 2 & 0 & 0 & 2 & \\
\hline Denmark & 3 & 0 & 0 & 3 & \\
\hline Finland & 5 & 0 & 0 & 5 & \\
\hline France & 1 & 0 & 0 & 1 & \\
\hline Gambia & 2 & 0 & 0 & 2 & \\
\hline Germany & 2 & 0 & 0 & 2 & \\
\hline Ghana & 10 & 0 & 4 & 14 & \\
\hline Greece & 3 & 0 & 0 & 3 & \\
\hline Guatemala & 6 & 0 & 0 & 6 & \\
\hline India & 8 & 701 & 14 & 723 & \\
\hline Islamic Republic of Iran & 3 & 0 & 0 & 3 & \\
\hline Jordan & 8 & 559 & 11 & 578 & \\
\hline Kenya & 9 & 114 & 4 & 127 & \\
\hline Kyrgyzstan & 4 & 0 & 0 & 4 & \\
\hline Malaysia & 7 & 0 & 3 & 10 & \\
\hline Mongolia & 4 & 0 & 0 & 4 & \\
\hline Namibia & 4 & 0 & 3 & 7 & \\
\hline Nepal & 6 & 0 & 0 & 6 & \\
\hline Nigeria & 7 & 0 & 2 & 9 & \\
\hline Norway & 3 & 0 & 0 & 3 & \\
\hline Pakistan & 5 & 0 & 0 & 5 & \\
\hline Paraguay & 3 & 0 & 0 & 3 & \\
\hline Peru & 4 & 0 & 0 & 4 & \\
\hline Poland & 2 & 0 & 0 & 2 & \\
\hline Romania & 5 & 0 & 0 & 5 & \\
\hline Russian Federation & 3 & 0 & 0 & 3 & \\
\hline South Africa & 5 & 0 & 0 & 5 & \\
\hline Spain & 3 & 0 & 0 & 3 & \\
\hline Sri Lanka & 4 & 0 & 0 & 4 & \\
\hline Sweden & 3 & 0 & 0 & 3 & \\
\hline Tunisia & 5 & 0 & 3 & 8 & \\
\hline Ukraine & 3 & 0 & 0 & 3 & \\
\hline United Republic of Tanzania & 8 & 0 & 2 & 10 & \\
\hline United States of America & 5 & 0 & 0 & 5 & \\
\hline Uruguay & 5 & 33 & 4 & 42 & \\
\hline Zambia & 10 & 0 & 3 & 13 & \\
\hline Total & 218 & 1407 & 58 & 1683 & \\
\hline
\end{tabular}

Figure 1. United Nations Mission in Eritrea and Ethiopia: International Military Contributions Since 2008 


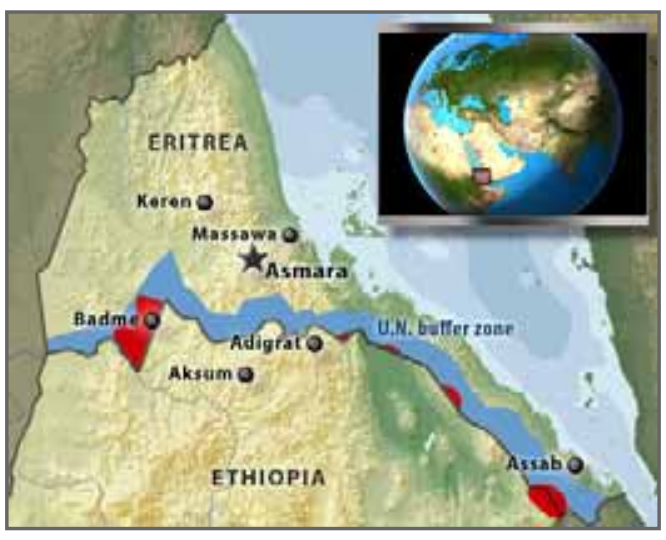

Figure 2. The Eritrean-Ethiopian Border Conflict

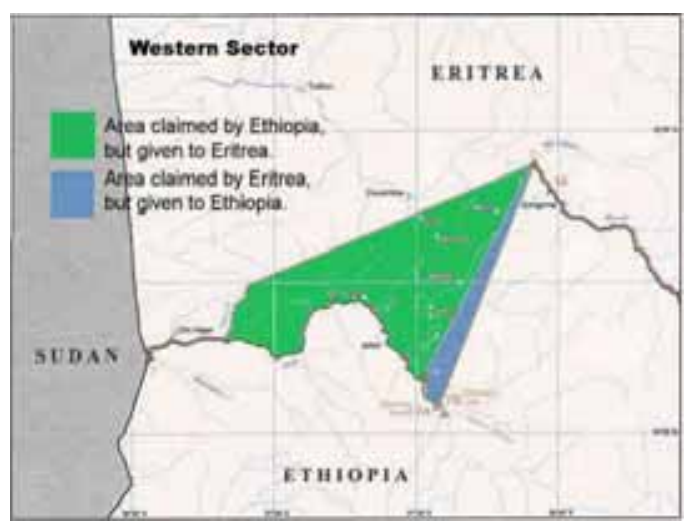

Figure 4. Decision of the Ethiopia-Eritrea Boundary Commission (EEBC) at the Hague, 13 April $2002-$ Western Terminus

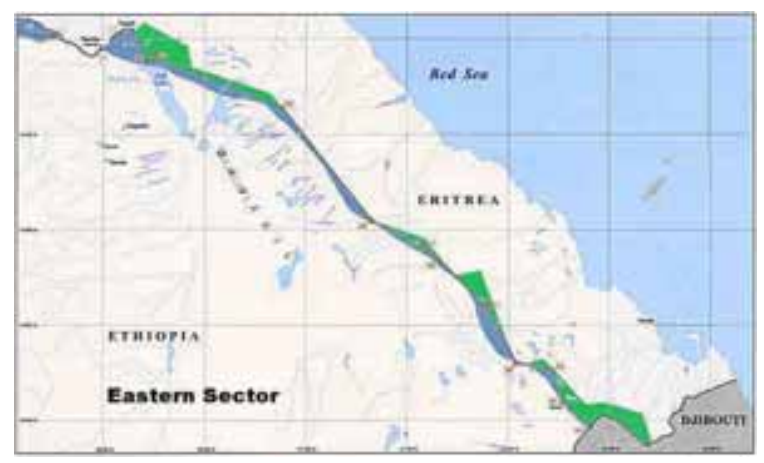

Figure 6. EEBC Decision - Eastern Terminus

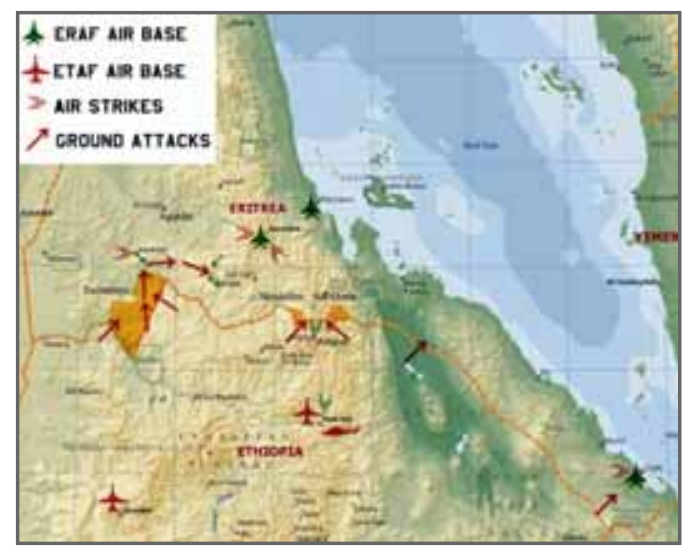

Figure 3. Ethiopian Military Operations

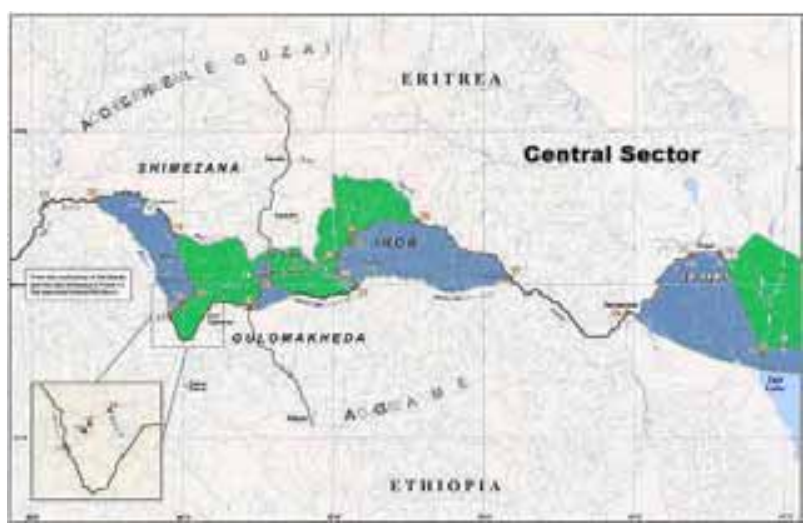

Figure 5. EEBC Decision - Central Terminus 